\title{
Porostrobus nathorstii (Leary \& Mickle) emend. and its spores from the Namurian of Illinois, USA
}

\author{
JIŘí BEK \& RICHARD L. LEARY
}

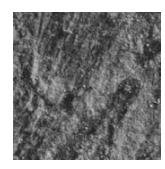

\begin{abstract}
The type collection of the Carboniferous selaginellalean lycopsid cone species Porostrobus nathorstii (Leary \& Mickle) emend. was palynologically re-examined for in situ microspores. Originally (Leary \& Mickle 1989) this species was proposed as monosporangiate with only megaspores, but now microsporangia yielded microspores compared to the dispersed miospore genus Cingulizonates (Dybová \& Jachowicz) Butterworth et al. All species of the genus Porostrobus Nathorst are, therefore, bisporangiate with in situ megaspores of the Setosisporites-type and microspores belong to the densospore group [genera Densosporites (Berry) Butterworth et al. and Cingulizonates]. The history of Porostrobus and Bothrodendrostrobus Hirmer cones is discussed with aspect of their possible relationship and ecological needs. $\bullet$ Key words: herbaceous lycopsids, in situ spores, Porostrobus, Bothrodendrostrobus, Carboniferous.
\end{abstract}

BEK, J. \& LEARY, R.L. 2012. Porostrobus nathorstii (Leary \& Mickle) emend. and its spores from the Namurian of Illinois, USA. Bulletin of Geosciences 87(1), 45-52 (1 figure, 1 table). Czech Geological Survey, Prague. ISSN 1214-1119. Manuscript received June 27, 2011; accepted in revised form November 9, 2011; published online January 25, 2012; issued February 29, 2012.

Jiři Bek, Institute of Geology v.v.i., Academy of Sciences, Rozvojová 269, 16500 Prague 6, Czech Republic; mrbean@gli.cas.cz•Richard L. Leary, Illinois State Museum, Springfield, Illinois 62706,_USA; Leary@ museum.state.ill.us

Carboniferous herbaceous lycopsids and their cones belong to a rarely reported group of fossil plants (Thomas 1997, 2005; Bek et al. 2001). Three groups of cones of Carboniferous herbaceous lycopsids can be distinguished on the basis of their in situ spores. All these fructifications are bisporangiate. The best known and the most often reported are cones of herbaceous forms of the genus Selaginella $\mathrm{Pa}$ lisot de Beauvoir. All these cones produced microspores of the genus Cirratriradites Wilson \& Coe [mostly C. saturni (Ibrahim) Schopf et al., see Bek et al. 2001] and megaspores compared with several species of the genus Triangulatisporites (Potonié \& Kremp) Karczewska (Thomas 1997, Bek et al. 2001). The second group is represented by unnamed type of Selaginella-like plant (Drábková, pers. comm.) found in the Bolsovian of the Radnice Basin, Czech Republic. In situ megaspores correspond with the dispersed genus Bentzisporites Potonié \& Kremp and microspores belong to the dispersed species Lundbladispora gigantea (Alpern) Doubinger.

The third group of Carboniferous fertile herbaceous lycopsids consists of the genera Porostrobus Nathorst and Bothrodendrostrobus Watson. Species of both genera produced megaspores of the Setosisporites-type and microspores of the densospore group (e.g. Balme 1995).

We re-examined the type collection of Porostrobus nathorstii Leary \& Mickle stored in the Illinois State Mu- seum, Springfield, USA from palynological view. The main goal was try to find in situ microspores, because all previously described Porostrobus species were bisporangiate and only $P$. nathorstii was defined as monosporangiate with only megaspores (Leary \& Mickle 1989). This re-examination was successful and the species $P$. nathorstii could be emended based on newly macerated in situ microspores.

\section{Material and methods}

The Allied Quarry is on Vandruff Island, located in the Rock River between the cities of Rock Island and Milan, Illinois (SE 1/4 Sec. 14, T.17 N., R.2 W., Milan Quadrangle). Specimens were collected from sediments that fill a channel eroded in Devonian Cedar Valley Limestone (Leary 1981). The channel is $6 \mathrm{~m}$ deep, 8 to $30 \mathrm{~m}$ wide, steep-sided, and flat-bottomed. The meandering channel had been eroded by a river flowing roughly east to west and is exposed in several quarries in Rock Island and Henry counties, Illinois.

The exact stratigraphic age of the fossil-bearing shale is difficult to determine. The shale is underlain by upper Middle Devonian Cedar Valley Limestone. Pleistocene erosion has removed nearly all the overlying Pennsylvanian strata 
in the quarry, but at a few points clean white to buff sandstone is present above the fossil-bearing shale. This sandstone contains Stigmaria casts and, on this basis, has been correlated with the "Stigmarian Sandstone", or Babylon Sandstone. Across the Rock River from the quarry, the same sandstone is interlayered with shale, carbonaceous shale, and impure coals. Using palynomorphs, these strata have been dated as Caseyville, and probably lower Langsettian (R. Peppers, pers. comm.). Based on the spores recovered from the shale the Allied Quarry shale deposit is considered to be of mid Namurian age (R. Peppers, pers. comm.). Macrofossils also indicate a Namurian age (Leary 1981).

Specimens of fossil plants are stored in the Illinois State Museum, Springfield, as ISM 417032-417049. In situ micro- (isolated from paratype ISM 417034) and megaspores and their slides are stored in the Geological Institute v.v.i., Academy of Sciences, Prague, Czech Republic. The spores are classified according to the system of dispersed spores suggested by Dettmann (1963), and Smith \& Butterworth (1967). In situ spores were compared directly with the original diagnoses (type specimens), descriptions and illustrations of dispersed spore species. Species determinations are based only on the original diagnoses, and not on the interpretations of subsequent authors. The terminology used for the descriptions of in situ spores is the same as that in the latest edition of the Glossary of pollen and spore terminology (Punt et al. 2007).

\section{Systematic section}

Class Lycopsida Scott, 1909

Order Selaginellales Prantl, 1874

\section{Genus Porostrobus Nathorst, 1914}

Type species. - Porostrobus zeilleri Nathorst, 1914.

Diagnosis. - See Leary \& Mickle 1989, pp. 1639-1641.

\section{Porostrobus nathorstii (Leary \& Mickle, 1989) emend.}

Holotype. - Specimen ISM 417032, Geological Collection, Illinois State Museum, Springfield; Leary \& Mickle 1989, fig. 3 .
Paratypes. - ISM 417033-417043, Geological Collections, Illinois State Museum, Springfield; Leary \& Mickle 1989, figs 4-6.

Collecting locality. - Shale deposits in the Allied Stone Company quarry, Milan, Rock Island County, Illinois (SE 1/4 sec. 14, T. 17 N., R. 2 W., Milan Quadrangle).

Stratigraphy. - Caseyville Formation, Morrowan Series, Early Pennsylvanian.

Emended diagnosis (modified from Leary \& Mickle 1989, p. 1639). - Bisporangiate cones up to $25 \mathrm{~mm}$ long and $7 \mathrm{~mm}$ in diameter (Fig. 1A, D, E, J), tapering slightly distally. Central axis up to $1 \mathrm{~mm}$ in diameter. Sporophylls lack a heel or keel, and possess a distal lamina up to $6 \mathrm{~mm}$ long. Tuft of leaves up to $20 \mathrm{~mm}$ long present at cone apex (Fig. 1A, B). Megasporangia containing a single megaspore tetrade (Fig. 1C-E, J) and microsporangia decreasing in size distally. Megaspores with prominent trilete arms; gulate; possessing branched hairs confined to an equatorial band. Trilete microspores with prominent equatorially thickened cingulum and thin radiated zona (Fig. 1F-I). Circular amb. Equatorial cingulum with thicker (darker) inner and lighter (outer) thinner portions. Inner body of the circular amb. Radial straight ridges from thicker to thinner part of cingulum and zona. The trilete mark is sometimes visible, reaching the diameter of the inner body.

Remarks. - Megaspores can be compared with the dispersed spore species Setosisporites praetextus (Zerndt) Potonié \& Kremp and microspores are comparable with the species Cingulizonates bialatus (Waltz) Smith \& Butterworth.

Description of specimens. - See Leary \& Mickle (1989, pp. 1640, 1643). In situ megaspores are 750-1,150 $\mu \mathrm{m}$ in diameter, microspores $35-52 \mu \mathrm{m}$ in diameter. Hairs of megaspores are from 140 to $220 \mu \mathrm{m}$ long.

\section{History of the genera Porostrobus, Bothrodendrostrobus and Bothrodendron}

The genus Bothrodendron Lindley \& Hutton is based (Lindley \& Hutton 1833) on compressions of large lycopsid

Figure 1. A - Porostrobus nathorstii (Leary \& Mickle) emend. ISM 417033. Two cones attached to a pedicle. Scale bar $1 \mathrm{~cm}$. B - Porostrobus nathorstii (Leary \& Mickle) emend. ISM 417036. Cone showing distal lamina of sporophyll. Scale bar $1 \mathrm{~cm}$. $\bullet$ C - Porostrobus nathorstii (Leary \& Mickle) emend. ISM 417048. Part of the cone with sporangia. Scale bar $1 \mathrm{~cm}$. • D - Porostrobus nathorstii (Leary \& Mickle) emend. ISM 417047 . Cone arrangement of sporangia and tetrads. Scale bar $1 \mathrm{~cm}$. E - Porostrobus nathorstii (Leary \& Mickle) emend. ISM 417049 . General view on the cone. Scale bar $1 \mathrm{~cm}$. F-I - in situ microspores isolated from Porostrobus nathorstii (Leary \& Mickle) emend. (ISM $417034-$ paratype) and compared to the dispersed miospore genus Cingulizonates bialatus (Waltz) Smith \& Butterworth. All $\times 500$. • J - Porostrobus nathorstii (Leary \& Mickle) emend. ISM 417034. Axis and the cone. Scale bar $1 \mathrm{~cm}$. 


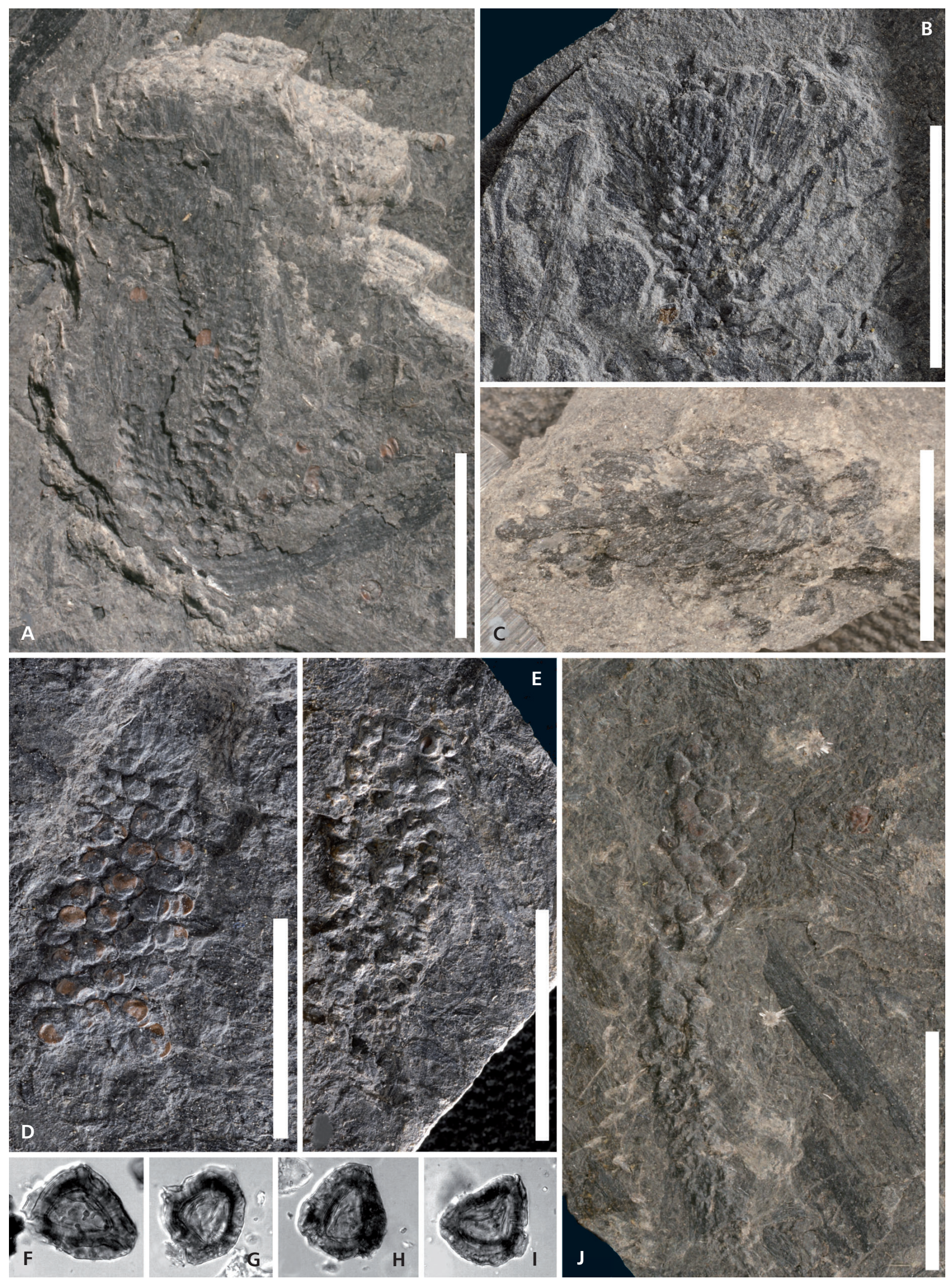


axes. But Lindley \& Hutton (1833) also included in the genus anatomically preserved axes and cones without evidence that conclusively relates any of permineralized material to the compressions. The connection of cones and vegetative parts was never been demonstrated.

Watson (1908) studied five cone specimens (coal-balls) and named them only as "the cones of Bothrodendron", but without any evidence about connection with Bothrodendron branches or trunks. But Hirmer (1927) referred Watson's specimens to Bothrostrobus Zalessky. Watson (1908) described in situ megaspores in megasporangia in the basal portions of the cones and microsporangia in the upper portions. Microsporangia are smaller than megasporangia. In situ megaspores are in four per megasporangium and possess typical hairs about $150 \mu \mathrm{m}$ long. The only informations given about the in situ microspores was that they are about $27 \mu \mathrm{m}$ in the diameter and possess an equatorial ridge. Watson (1908) wrongly attributed the cones to Bothrodendron mundum Williamson and stated that cones are different from those of arborescent lycopsids of the Lepidostrobus-type.

Hirmer (1927) named this type of cones for the first time as Bothrostrobus mundus Hirmer. Chaloner (1967) placed Bothrostrobus olryi Rénier (the type species of the genus) in synonymy with Lepidostrobus (Brongniart) Brack-Hanes \& Thomas and recognised that cones reported by Watson (1908) cannot be referred to Lepidostrobus, i.e. to arborescent lycopsids. On the other hand, Chaloner (1967) realised that Watson's cones do not belong to Bothrodendron mundum. Therefore, Chaloner (1967) proposed the name Bothrodendrostrobus watsonii Chaloner for Watson's cones. It means that Watson's cones have been known by two different names, Bothrostrobus mundus and Bothrodendrostrobus watsonii but important is, that nothing was known about their parent plants. Generic name Bothrodendrostrobus was first used in the index of Hirmer (1927, p. 701) for some material that he named Bothrostrobus in the text. Later Chaloner (1967) validated the name Bothrodendrostrobus by supplying a description and designating the Watson's material as the type specimens.

Stubblefield \& Rothwell (1981) described thirteen specimens of permineralized megagametophytes and embryos from the Langsettian of England, UK. They compared the megaspores with the dispersed spores species Setosisporites praetextus f. minor Chaloner. Stubblefield \& Rothwell (1981, pp. 62, 68, 69) gave a brief review about the complicated position and classification of these cones and their parent plants and compared Bothrodendrostrobus with the extant genus Isoetes Linnaeus based on the embryogeny and stated that it is different from arborescent lycopsids of the Lepidocarpon-Lepidophloios-type. They also reinstalated the combination Bothrodendrostrobus mundus and proposed B. watsonii as synonymum of it. Important is that Stubblefield \& Rothwell (1981) stated (based upon the embryological similarity known for Bothrodendrostrobus and the extant Isoetales), that parent plant of Bothrodendrostrobus was not an arborescent lycopsids with a stigmarian root system, but it have been a much smaller plant with cormose rooting-system like that of the Pennsylvanian genus Paurodendron Fry (Stubblefield \& Rothwell 1981, p. 633).

Nathorst $(1894,1904)$ reported a small cone from the Mississippian of Spitzbergen as Lepidostrobus zeilleri Nathorst and he later (Nathorst 1914) erected the new genus Porostrobus for this species and described in situ microspores with prominent equatorial cingulum belonging to the densospore group. The in situ megaspores can be assigned to the dispersed species Setosisporites hirsutus var. brevispinosa (Zerndt) Potonié \& Kremp (Chaloner 1967).

Emendation of the genus Porostrobus was proposed by Bharadwaj (1958) who re-investigated the original specimens of $P$. zeilleri Nathorst collected from the Mississippian of Lower Spitzbergen, assigned the in situ microspores to the genus Densosporites (Berry) Butterworth et al. and described the in situ megaspores as gulate with verrucate to granulate exine and developed contact area.

Chaloner (1958) described a new species Selaginellites canonbiensis Chaloner with in situ megaspores that he compared to the dispersed spore species Setosisporites hirsutus (Loose) Ibrahim and in situ microspores of the Cingulizonates-type. Later Chaloner (1962) realized similarity with Porostrobus and suggested the new combination Porostrobus canonbiensis (Chaloner) Chaloner.

The third fertile species of Porostrobus was described by Leary \& Mickle (1989) as P. nathorstii when they also emended the genus. Leary \& Mickle (1989) recovered only megaspores belonging to the dispersed species Setosisporites praetextus making Porostrobus nathorstii the only monosporangiate species of the genus within their original concept of the species.

Taxonomic and nomenclatoric problems with cones of the Bothrodendrostrobus and Porostrobus-type and their parent plants are still confusing and complicated (for anatomical details and detailed discussion see Bharadwaj 1958, pp. 71-74; Chaloner 1958, pp. 250, 251; Stubblefield \& Rothwell 1981, p. 626; Leary \& Mickle 1989, pp. 1643, 1644).

\section{Ecology \\ of Porostrobus/Bothrodendrostrobus}

Leary \& Mickle (1989) described P. nathorstii together with sphenophylls (Sphenophyllum tenerrimum Stur, 
Jiři Bek \& Richard L. Leary • Porostrobus and its spores from the Namurian of Illinois

Table 1. Selected dimensions of Bothrodendrostrobus and Porostrobus cones, their stratigraphical positions and their in situ spores.

\begin{tabular}{|c|c|c|c|c|c|c|c|}
\hline & $\begin{array}{l}\text { Diameter } \\
(\mathrm{mm})\end{array}$ & $\begin{array}{l}\text { Length } \\
(\mathrm{mm})\end{array}$ & $\begin{array}{l}\text { Diameter of axis } \\
(\mathrm{mm})\end{array}$ & $\begin{array}{l}\text { In situ } \\
\text { microspores }\end{array}$ & In situ megaspores & $\begin{array}{l}\text { Stratigraphical } \\
\text { position }\end{array}$ & References \\
\hline Bothrodendrostrobus mundus & $2-10$ & $>10$ & 3 & densospores & $\begin{array}{l}\text { Setosisporites praetextus } \mathrm{f} . \\
\text { minor }\end{array}$ & Langsettian & Chaloner (1967) \\
\hline Porostrobus zeilleri & 6 & $>20$ & 1 & Densosporites & $\begin{array}{l}\text { Setosisporites hirsutus var. } \\
\text { brevispinosus }\end{array}$ & Mississippian & Chaloner (1962) \\
\hline Porostrobus canonbiensis & 3.5 & $>15$ & $?$ & $\begin{array}{l}\text { Cingulizonates } \\
\text { loricatus }\end{array}$ & & Westphalian & $\begin{array}{l}\text { Bharadwaj } \\
\text { (1958) }\end{array}$ \\
\hline Porostrobus nathorsti & $4-7$ & $18-36$ & 1 & Not macerated & Setosisporites praetextus & Namurian & $\begin{array}{l}\text { Leary \& Mickle } \\
\text { (1989) }\end{array}$ \\
\hline Porostrobus nathorsti & $4-7$ & $18-36$ & 1 & Cingulizonates & Setosisporites praetextus & Namurian & Herein \\
\hline
\end{tabular}

S. sublaure Purkyňová, S. cuneifolium Sternberg), calamites [Mesocalamites cistiformis Stur, Asterophyllites charaeformis (Sternberg) Goeppert, A. equisetiformis Brongniart], Sphenopteris preslesensis Stockmans \& Willière, Alethopteris lonchitica Schlotheim, Gulpenia limburgensis Gothan \& Jongmans and Palaeopteridium reussi (Ettingshausen) Kidston. Lycopods are represented by Lepidostrobus cones, Lepidocarpon megasporophylls, Lepidophylloides leaves, Stigmaria and Lepidodendron axis. No vegetative structures unambiguously associated with Porostrobus cones have been found (Leary \& Mickle 1989).

Cone specimens of $P$. nathorstii consist of two types. Some cones are essentially intact in that sporangium is found covering mature megaspore tetrads, and the distal sporophyll laminae and tuft are intact. Other cone specimens consist of little more than megaspore tetrads in the positions of sporangia in a cone, but the sporangium, laminae tissue, and axis are not preserved. No specimen has been observed that appeared to has dehisced sporangia. Based on these observations and indications that these cones were transported, it is possible to speculate that whole cones were shed from the parent plant intact (Leary \& Mickle 1989).

Cones were found in sediments completely filled channels eroded in a nearly level limestone surface (Leary 1981). Isolated $S$. praetextus megaspores are concentrated in the highly fissile black shale at the top of the sequence. Parent cones are restricted to these upper black shales. Almost none of the channel sediments are bioturbated, indicating that plants did not grow in the channels, even when the channels filled with sediments (Leary \& Mickle 1989). This observation suggests that cones and megaspores were transported prior to burial. Based on the associated flora, the Porostrobus-bearing plants probably grew in area adjacent to channels.

Leary \& Trask (1985) interpreted plant assemblage of the Rock Island County as upland flora. This term has been used to designate distinctive nonswamp floras. The upland plants grew on soils derived from limestone bedrock, and many were stream banks and ultimately were deposited in stream channels with minimal transport. Generally upland flora includes a number of plant taxa which are unknown in coal swamp. The presence of a permanent body of water in the channels apparently permitted the growth on the drier sites in Rock Island of genera (e.g. Lepidodendron Sternberg and Mesocalamites Hirmer) common to coal swamp (Leary \& Trask 1985).

The greatest similarity appears to be with the flora of the Czech part of the Upper Silesian Basin, Czech Republic (Šusta 1928, Purkyňová 1970). Here, Havlena (1970) recognised several microenvironments within Namurian hygrophile environment in addition to a major separation of the hygrophile and mesophile environments. The mesophile (i.e. upland) flora described by Havlena (1970) was present only as fragments whereas preservation of the plants in the Rock Island is excellent (Leary \& Trask 1985).

It should be noted that Porostrobus and Bothrodendrostrobus were not the only densospores-producers because this type of microspores has also been recovered from a sub-arborescent lycopsid of the genus Omphalophloios White (e.g., Wagner et al. 2003, Opluštil et al. 2010).

Miospores of the densospore group [i.e. Densosporites, Cristatisporites (Potonié \& Kremp) Butterworth et al. and Cingulizonates)] first appeared in Devonian strata although they are most abundant throughout the Pennsylvanian in most Euramerican coalfields. They are not very important from a stratigraphical view but they belong to ecologically significant spores. Smith (1962) assigned densospores-dominated parts of coal seams to the densospore phase which is interpreted as the ombrotrophic stage of mire development as is also supported by the high inertinite and very low mineral matter content (see also Butterworth 1964, Habib \& Groth 1967). On the other hand, different authors (e.g. Littke 1987, Strehlau 1990, Opluštil et al. 1999) identified a densospore phase from coal seams which contained sedimentary partings or increased ash content and which evidently, did not develop into an ombrotrophic mire. Eble \& Grady (1990) suggested 
an ecological link between densospores-producing plants and brackish conditions.

Stubblefield \& Rothwell (1981) discussed the palaeoecological preference of the parent plants of Bothrodendrostrobus based on the dispersed occurrences of Setosisporites megaspores. They suggested that Bothrodendrostrobus may have grown in a swampy environment. Stubblefield \& Rothwell (1981) found megagametophyte and embryos in isolated spores. It is, therefore, probable, that megagametophyte development, fertilization, and embryogeny in Bothodendrostrobus occured (like in the extant Isoetales) in an aqueous environment after the spores were released from sporangia (Stubblefield \& Rothwell 1981, p. 632). The pores on the megaspore surface described by Stubblefield \& Rothwell (1981), which were initially covered and later exposed, may be a mechanism for gaseous exchange or possibly for water regulation (Stubblefield \& Rothwell 1981).

Piérart (1968) described two main assemblages of dispersed megaspores, "wet" with Cystosporites Schopf, Triangulatisporites, Lagenicula (Bennie \& Kidston) Potonié \& Kremp and Tuberculatisporites (Ibrahim) Potonié \& Kremp and "less wet" with Zonalesporites (Ibrahim) Potonié \& Kremp and Setosisporites (Ibrahim) DybováJachowicz et al.

Similar results are described by Bartram (1987) who recognised five palynological phases based on megaspore record and petrological analysis. Generally drier Phase 3 is characteristic by the occurrence of Spencerisporites radiatus (Ibrahim) Bek et al., Setosisporites hirsutus (Loose) Ibrahim, Lagenicula subpilosa Ibrahim and Zonalesporites.

It means that Setosisporites and Zonalesporites megaspores (parent fructifications of both genera produced densospores) are often recorded together as dispersed. It suggests similar ecological needs of their parent plants.

The results of Piérart (1968), Bartram (1987), Leary \& Trask (1985) and Leary \& Mickle (1989) suggested, based on the study of compression specimens and dispersed megaspores, that Porostrobus could preferred less wet environment probably corresponding with ombrotrophic type stage of mire development.

Only Stubblefield \& Rothwell (1981) described Setosisporites megaspores of the Bothrodendrostrobus origin (i.e. from permineralised cones) and stated that parent plants may have grown in swampy environment, similar to rheotrophic type stage of mire development.

It is possible that parent plants of compression specimens of Porostrobus cones preferred different ecological conditions (ombrotrophic-type of swamp) than permineralised (coal-balls) specimens of Bothrodendrostrobus (rheotrophic-type of swamp), although both cone genera produced the same spores.

\section{Discussion}

All cones of the genera Bothrodendrostrobus and Porostrobus have yielded the same types of micro- and megaspores that can be closely compared with the densospore group (microspores) and the spore genus Setosisporites.

Morphologically the simplest spore types, i.e. trilete, laevigate thin-walled (e.g. calamospores) or laevigatemicrogranulate-microverrucate (e.g. genera Leiotriletes Naumova, Granulatisporites Ibrahim and Apiculatisporis Potonié \& Kremp) miospores have been recovered from several plant species and genera, sometimes even from different plant groups (Balme 1995). This is not the case for microspores of the densospore group and megaspores of the genus Setosisporites as such morphologically more complicated spores were usually produced by the only parent plant genus (Balme 1995). This means that from a palynological point of view the two genera Bothrodendrostrobus and Porostrobus may be hypothetically synonymous. Additional circumstantial evidence is that the parent plants of both cones were herbaceous lycopsids. Chaloner (1958) originally named his specimen of Porostrobus as Selaginellites Zeiller and also Stubblefield \& Rothwell (1981, p. 633) stated that Bothrodendrostrobus was not produced by arborescent lycopsids with stigmarian root system, but that it may have been a much smaller plant with cormose rooting system like Paurodendron, i.e. a Selaginella-like plant.

We cannot be sure about the synonymity of Porostrobus and Bothrodendrostrobus because all specimens of Porostrobus are preserved as compressions while all Bothrodendrostrobus specimens are from coal-balls. We know some anatomical data from Bothrodendrostrobus cones but they cannot be observed on Porostrobus specimens. Also morphological informations described on Porostrobus cones cannot be proved for specimens of Bothrodendrostrobus. Maybe both genera represent different modes of the preservation (like Sigillariostrobus Hirmer and Mazocarpon Benson), but we still have no direct evidence for such a conclusion.

\section{Acknowledgement}

We acknowledge financial support from the Grant Agency of the Czech Republic (IAA301110701) and the Research Program (AVOZ30130516) of the Institute of Geology v.v.i., Academy of Sciences, Prague. Special thanks to M. Libertín from the National Museum, Prague, Czech Republic and E. Schroeder from the Illinois State Museum, Springfield, USA for excellent photographs of plant specimens. We are obliged to B.A. Thomas from the University of Aberystwyth, UK and S. Opluštil from the Faculty of Sciences, Charles University, Prague, Czech Republic for reviews, helpful comments and suggestions. 


\section{References}

BALME, B.A. 1995. Fossil in situ spores and pollen grains: an annotated catalogue. Review of Palaeobotany and Palynology 87, 81- 323. DOI 10.1016/0034-6667(95)93235-X

BARTRAM, K.M. 1987. Lycopod succession in coals: an example from the Low Burnley Seam (Westphalian B), Yorkshire, England, 187-199. In Sсотт, A.C. (ed.) Coal and Coal-bearing strata: Recent advances. Geological Society, Special Publications 32.

Bek, J., Opluštil, S. \& Drábková, J. 2001. Two species of Selaginella cones and their spores from the Bohemian Carboniferous continental basis of the Czech Republic. Review of Palaeobotany and Palynology 114, 57-81. DOI 10.1016/S0034-6667(00)00069-5

Bharadwaj, D.A. 1958. On Porostrobus zeilleri Nathorst and its spores with remarks on the systematic position of $P$. benholdi Bode and phylogeny of Densosporites Berry. The Palaeobotanist 7, 67-75.

Butterworth, M.A. 1964. Die vertliegung der Densosporites sphaerotriangularis in Westphalian B der westpenninschen steinkohlenfelder Englands. Fortschritte in der Geologie von Rheinland und Westphalen 12, 3173-330.

Chaloner, W.G. 1958. A Carboniferous Selaginellites with Densosporites microspores. Palaeontology 1, 245-253.

Chaloner, W.G. 1962. A Sporangiostrobus with Densosporites microspores. Palaeontology 5, 73-85.

Chaloner, W.G. 1967. Lycophyta, 437-802. In Boureau, E. (ed.) Traité de Paléobotanique. Tome II. Masson et Cie, Paris.

Dettmann, M.E. 1963. Upper Mesozoic microfloras from southeastern Australia. Proceedings of the Royal Society of Victoria $77,1-148$.

Eble, C.F. \& Grady, W.C. 1990. Paleoecological interpretation of a Middle Pennsylvanian coal bed from the central Appalachian Basin, U.S.A. International Journal of Coal Geology 16, 255-286. DOI 10.1016/0166-5162(90)90054-3

Habiв, B. \& GRoth, P.K.H. 1967. Paleoecology of migrating Carboniferous peat habitats. Palaeogeography, Palaeoclimatology, Palaeoecology 3, 185-195. DOI 10.1016/0031-0182(67)90013-2

HavlenA, V. 1970. Ecology and mode of deposition of the macroflora in cyclothems of the Ostrava Formation (Namurian A). Věstník Ústředního ústavu geologického 45, 291-294.

Hirmer, M. 1927. Handbuch der Pälaobotanik. Band I: Thallophyta, Bryophyta, Pteridophyta. 724 pp. R. Oldenburg Verlag, München \& Berlin.

LEARY, R. 1981. Early Pennsylvanian geology and paleobotany of the Rock Island County, Illinois area. Part 1: Geology. Illinois State Museum, Report of Investigation, 37.

LeAry, R. \& Mickle, J.E. 1989. Porostrobus nathorstii, sp. nov.: a new species of lycopsid cone from the early Pennsylvanian of Illinois. American Journal of Botany 76, 1638-1645. DOI $10.2307 / 2444401$

Leary, R.L. \& Trask, C.B. 1985. Early Pennsylvanian paleotopography and depositional environments, Rock Island
County, Illinois. Illinois State Geological Survey Guidebook $18,1-42$.

LindLEy, J. \& HutTon, W. 1833. The fossil flora of Great Britain I. 218 pp. J. Ridgway, London.

LitTKe, R. 1987. Petrology and genesis of Upper Carboniferous seams from the Ruhr region, West Germany. International Journal of Coal Geology 7, 147-184.

DOI 10.1016/0166-5162(87)90047-4

Nathorst, A.G. 1894. Zur fossilien Flora der Polander. I. Zur paläozoischen Flora der Arktischen Zone. Kongliga Svenska Vetenskaps-Akademiens Handlingar 26, 1-80.

Nathorst, A.G. 1904. Sur la flore fossile regions antarctiques. Compte Rendu de la Academie des Sciences Paris 138, 1447-1450.

NATHORST, A.G. 1914. Zur fossilien Flora der Polarlander I(4): Nachträge zur paläozoischen Flora Spitzbergens. 110 pp. Norstedt \& Söner, Stockholm.

Opluštil, S., BeK, J. \& SchultKa, S. 2010. Re-examination of the genus Omphalophloios White, 1893 from Upper Silesian Basin. Bulletin of Geosciences 85(1), 123-136.

Opluštil, S., SÝKorovÁ, I. \& BeK, J. 1999. Sedimentology, coal petrology and palynology of the Radnice Member in the S-E part of the Kladno-Rakovník Basin, Central Bohemia (Bolsovian). Acta Universitatis Carolinae, Geologica 43, 599-623.

PiÉRART, P. 1968. Les associations de microspores et de megaspores dans une couche (couche 70 de Beeringen) du Westphalien A superieur de la Campine (Belgique). Review of Palaeobotany and Palynology 7, 275-283.

DOI 10.1016/0034-6667(68)90033-X

Punt, W., Hoen, P.P., Blackmore, S., Nilsson, S. \& Le Thomas, A. 2007. Glossary of pollen and spore terminology. Review of Palaeobotany and Palynology 143, 1-81. DOI 10.1016/j.revpalbo.2006.06.008

PrantL, K.A.E. 1874. Lehrbuch der Botanik. 498 pp. W. Engelmann, Leipzig.

PuRKYŇOvÁ, E. 1970. Die Unternamurflora des Beckens von Horní Slezsko (ČSSR). [The lower Namurian flora of the Upper Silesian Basin, Czechoslovakia.] Paläontologische Abhandlunge Paläobotanik, Abteilung B 3(2), 129-268.

Scotт, D.H. 1909. Studies in Fossil Botany, $2^{\text {nd }}$ edition. 552 pp. A. \& C. Blafl Ltd., London.

SMiTh, A.H.V. 1962. The palaeoecology of Carboniferous peats based on the miospores and petrography of bituminous coals. Proceedings of the Yorkshire Geological Society 33, 423-474. DOI 10.1144/pygs.33.4.423

Smith, A.H.V. \& Butterworth, M.A. 1967. Miospores in the coal seams of the Carboniferous of Great Britain. Special Papers in Palaeontology 1, 1-324.

Strehlau, K. 1990. Facies and genesis of Carboniferous coal seams of Northwest Germany. International Journal of Coal Geology 15, 245-292. DOI 10.1016/0166-5162(90)90068-A

Stubblefield, S.P. \& Rothwell, G.W. 1981. Embryogeny and reproductive biology of Bothrodendrostrobus mundus (Lycopsida). American Journal of Botany 68(5), 625-634. DOI $10.2307 / 2442789$ 
Šusta, V. 1928. Stratigrafie des Ostrau-Karviner Steinkohlenreviers im lichte der Paläontologie. Der Köhlenbergau des Ostrau-Karviner Steinkohlenreviers I, 385-484.

Thomas, B.A. 1997. Upper Carboniferous herbaceous lycopsids. Review of Palaeobotany and Palynology 95, 129-153. DOI 10.1016/S0034-6667(96)00032-2

Thomas, B.A. 2005. A reinvestigation of Selaginella species from the Asturian of the Zwickau coalfield, Germany and their assignment to the new sub-genus Hexaphyllum. Zeitschrift der Deutschen Gesellschaft für Geowissen- schaften 156(3), 1-12.

DOI 10.1127/1860-1804/2005/0156-0403

Wagner, R.H., Brousmiche-Delcambre, C. \& Coquel, R. 2003. Una Pompeya Paleobotanica: historia de una marisma carbonifera sepultada por cenizas volcanicas, 448-475. In Nuche, R. (ed.) Separata de Patrimonio Geológico de Castilla-La Mancha. Enresa, Madrid.

Watson, D.M.S. 1908. The cone of Bothrodendron mundum. Memoires of the Manchester Literary and Philosophical Society 52, 1-15. 